\title{
Integrating Finance into Global Production Networks
}

\author{
NEIL M. COE*, KAREN P.Y. LAI*, DARIUSZ WÓJCIK士 \\ *Department of Geography, National University of Singapore, 1 Arts Link, Kent Ridge, Singapore 117570. Emails: \\ geonmo@nus.edu.sg and karenlai@nus.edu.sg \\ \pm School of Geography and the Environment and St. Peter's College, Oxford University, South Parks Road, Oxford \\ OX1 3QY, UK. Email: dariusz.wojcik@spc.ox.ac.uk (corresponding author)
}

\begin{abstract}
While successful in its aim of 'globalizing' regional development, the Global Production Network (GPN) approach has thus far paid less attention to the role of finance in the dynamics of the global economy and regional development. This lacuna is significant as finance is arguably even more globalised and networked than production. To address this gap the paper distills the concept of the Global Financial Network (GFN) from financial geography and related scholarship, with advanced business services, world cities, and offshore jurisdictions at the core. Interactions between the GPN and the GFN are discussed, focusing on the financing and financializing of GPNs and the co-evolution of globalization and financialisation. Integrating finance into GPN research entails more than a simple extension of the approach; it would also enrich it conceptually, and enable it methodologically and empirically.
\end{abstract}

Keywords: Global Production Networks, Global Financial Networks, advanced business services, world cities, offshore jurisdictions, financialization

JEL codes: F23, F65, O16, R11

\section{Introduction}

First coined in 2002, the Global Production Network (GPN) approach is a framework for analyzing the global economy and its impacts on regional development, with regions being defined in multi-scalar terms and analyzed as states, subnational regions or cities (HENDERSON et al., 2002). The approach posits that the global economy is driven by processes of strategic coupling between actors representing particular regions, such as government agencies, local businesses or business associations, and lead firms in GPNs i.e. 'powerful firms that orchestrate and coordinate complex GPNs in their respective industries' (YEUNG, 2009, p. 330). The objective of regional development in these conditions is to 
'plug' the region into GPNs, but also to enhance and capture value for the benefit of the region in various ways, including through taxation, upgrading of skills or investment in infrastructure. Value capture and the coupling process are affected by the relative bargaining power of regional institutions visà-vis lead firms, resulting in temporary and flexible configurations of firm and non-firm actors. Consequently, regions need policies that enhance their position in existing GPNs, but they also need to be prepared for the possibility of decoupling between the GPN and the region, and to develop assets attractive to prospective GPNs for new rounds of strategic coupling (MACKINNON, 2012).

The GPN approach has inspired a large body of literature, with several special issues of journals in geography, regional studies, and beyond. One major contribution of GPN research has been to 'globalize' regional development, viewing 'the region' as a porous territorial formation whose boundaries are transcended by a broad range of network connections. However, the GPN approach has thus far only seen limited discussion of the role of finance - i.e. financial actors, markets, and practices - in the dynamics of the global economy and regional development. GPN scholars are starting to recognize this, with a recent review identifying the lack of engagement with finance as one of the major gaps in the GPN literature, and stressing the need to 'drill down into the impacts of financialisation at the sectoral and corporate level on GPN structures and dynamics' (COE, 2012, p. 392). Other commentators (AOYAMA et al., 2011; TAYLOR, 2012) have also highlighted the intersection of finance with the geographies of production as an important but still neglected nexus for understanding economic processes and developmental outcomes ${ }^{\mathrm{i}}$. Financial geography research, in turn, has also tended not to focus on the intersections of finance and production, a concern reflected in recent calls to (re)ground finance within the 'real economy' in order to examine how the two are entangled (HALL, 2013). Overall, there is clearly insufficient attention to how production is financed in economic geography scholarship and regional studies in general. While there is some pioneering research that combines ideas on financialization and global value chains - a cognate approach to GPNs (e.g. GIBBON, 2002; PALPACUER, 2008; MILBERG and WINKLER, 2010; BAUD and DURAND, 2012), these contributions are so far the exceptions to the rule.

To address these concerns, this paper proposes integrating finance much more centrally into the GPN approach. Finance is arguably even more globalized and networked than production, and should be pivotal to the GPN approach; no GPN can function without financing and financial logics permeate the entire operations of GPNs. Moreover, understanding finance is indispensable to empirical studies of GPNs, especially with regards to developing measures of value creation, capture and transfer. These are core conceptual components of the GPN framework but have yet to be fully grappled with or elucidated empirically (COE et al., 2008). The paper starts by distilling the concept of Global Financial Networks 
(GFNs), with Advanced Business Services (ABS), World Cities (WCs), and Offshore Jurisdictions (OJs) as the principal building blocks. This is followed by a discussion of how GFNs intersect with GPNs, focusing on the financing and financialisation of GPNs. Finally, we present ideas on how to operationalize these intersections in terms of data and methods. Our overall aim is to show that integrating finance into the GPN approach would enrich it conceptually, and enable it methodologically and empirically.

\section{$2 \quad$ Distilling Global Financial Networks}

As part of this dialogue between GPN and financial geography research, we wish to establish the idea of the GFN as a framework for understanding financial geographies and their impacts on firm behaviour and regional development. Over the past few decades, financial geographers have written much on global financial systems, flows and networks, but have stopped short of treating them as an integrative framework. Yet these financial activities form a global economic network that is distinctive in terms of its operation and impact, and specific actors (associated with ABS) and territories (such as WCs and OJs) are particularly important in shaping economic practices and regional development.

Traditionally financial geographers have focused on the changing spatial structures of the international financial system and financial industry. Early research was concerned with the regulation and governance of the international financial system (LEYSHON, 1992; CORBRIDGE, 1994; LEYSHON and THRIFT, 1997a) and debates about the dynamic relationships between finance capital and nation-states (CLARK, 1999; MARTIN, 1999; BUDD, 1999; HELLEINER, 1995). This political economy approach was complemented by more socio-cultural explanations of the persistence and increasing importance of international financial centres (IFCs) as strategic basing points for global capital. The territorial embeddedness of specific localities in the production and reproduction of global finance was explained by particular social and cultural constructions of people and places (LEYSHON and THRIFT, 1997b; BUDD, 1999; PORTEOUS, 1999; THRIFT, 1998). While initial studies focused on analysing individual WCs (SASSEN, 1991; ZUKIN, 1992; THRIFT, 1994; CLARK and O'CONNOR, 1997), relational approaches became more important in explaining how and why such financial centres develop and/or maintain their roles and prominence. Much of the financial geography literature on IFC networks has concentrated on inter-city connections in Anglo-American economies (FAULCONBRIDGE, 2004; BEAVERSTOCK et al., 2005; WÓJCIK et al.; 2007; WÓJCIK, 2013), but there is also a growing body of work on emerging economies (LAI, 2006; 2012; SMITH and SWAIN, 2010; WÓJCIK and BURGER, 2010) and alternative financial networks, such as Islamic financial products centred on the Middle East (BASSENS et al., 2010; POLLARD and SAMERS, 2011). 
A key strength of the GPN framework is the integration of different actors and spatialities of production into networked relationships in explaining the processes and impact of global production activities. In this vein, we argue that the idea of a GFN is compelling as finance is just as global and networked as production, if not more so, due to the interlocking structures and interdependent nature of financial systems and institutions. There has been growing awareness of the saliency of the networked nature of finance, particularly following the 2008 global financial crisis and credit crunch, with banks being seen as not only too big but also too interconnected to fail due to the systemic risk that they pose. This observation has led some economists and policy makers to argue against the increasing size, complexity and interconnectedness of financial institutions and systems as they may undermine global economic stability (STIGLITZ, 2010; HALDANE and MAY, 2011). The concern with the systemic impact of finance is reflected in a growing body of work on 'financialisation', which examines the growing power of financial markets and institutions on national economies (BLACKBURN, 2006; DORE, 2008), firms (FROUD et al., 2002; KRIPPNER, 2005; HO, 2009; PIKE and POLLARD, 2010), and households and individuals (LEYSHON et al., 2004; ENGELEN, 2008; LANGLEY, 2008; FRENCH et al., 2011). This concept of financialisation has particular resonance for understanding the operation and dynamics of firm strategies and production networks (as we will elucidate in Section 3.2). At this point, our objective is to bring together the key actors (ABS) and territories (WCs and OJs), within an integrative financial geography framework (i.e. the GFN) (see Figure 1) that would capture the networked nature of finance and provide scope for exploring its systemic impacts and territorial dimensions.

Firstly, why do we conceptualize finance and professional business services under the broad category of $\mathrm{ABS}^{\mathrm{ii}}$ within the GFN framework? The power of finance is not only enacted through banks, insurance companies, credit rating agencies, asset management companies, pension funds and other financial institutions; ABS are vital in enabling the work of financial institutions and connecting finance to firms in the wider economy. The networked nature of financial activities is intermediated and facilitated by ABS such as accountancy, law and business consultancy (BRYSON, 2000; JONES, 2003; BEAVERSTOCK, 2004, 2007). As demonstrated by Wójcik (2013b), these sectors hold considerable power in mobilizing the geographies of financial production, financial trading and investment vehicles (IVs), which enable and delineate the transnational activities of both financial and non-financial firms. The work of financial institutions is impossible without ABS firms; conversely, much of ABS activity is driven by financial markets and institutions (although the latter is also shaped by the logics and practices of the former). Taken together, they are all providers of highly specialized knowledge that facilitates and shapes the increasingly complex configuration and operation of GPNs (DICKEN, 2011). Given their 
interdependence and entangled nature, we propose a broad analytical category of ABS that encompasses both finance and ABS firms for this framework. We will further elaborate in the next section on this pivotal role of ABS at the intersection of GFNs and GPNs.

The work of ABS is spatialised and has territorial outcomes in the form of WCs and OJs. ABS firms tend to cluster in WCs to take advantage of agglomeration economies and other socio-cultural advantages (e.g. SASSEN 1991; THRIFT 1994), co-locating with the headquarters of non-ABS firms. Early research on WCs has focused on their roles as 'basing points' for capital and 'command and control centres' of the global economy as TNCs organize global production on larger and more complex scales (FRIEDMANN AND WOLF, 1982; FRIEDMANN, 1986). Rather than sheer presence of TNC headquarters, studies also emphasize the practice of global control, i.e. ABS firms that intermediate and facilitate actual control and management (SASSEN 1991; 2001). While WCs may be differentiated based on corporate hierarchies (of TNCs and ABS firms) and global control functions, they are also embedded in networked relations and dynamic inter-city linkages (TAYLOR, 2004). Relational approaches to WC development reveal new nodes and networks in the global economy that reflect the dynamic nexus of capital flows, global production and urban development (ROBINSON, 2005; LAI, 2009). As key nodes in an evolving global network, WCs are vital territories in the spatial articulation and manifestation of intersecting global finance and production networks.

Another significant impact of ABS is in influencing corporate strategies and directing financial flows through the design and use of IVs with different tax, legal and regulatory implications (WÓJCIK, 2013b). This brings us to the topic of offshore finance and the need to treat OJs as an integral component within a framework that examines global flows and networks of investments and profits. As pointed out by MAURER (2008: 160), 'far from being a marginal or exotic backwater of the global economy, offshore in many ways is the global economy' (original emphasis). While it is difficult to measure the scale and magnitude of offshore financial activities given their opaque nature, a recent special report of THE ECONOMIST (2013b) estimates that there are between 50 to 60 active OJs, with over 30 percent of global FDI being 'booked' through them. Recent scandals involving Starbucks, Amazon and Google in the UK have highlighted the problem of tax avoidance (BBC News, 2012), but investors also use these OJs for other forms of institutional arbitrage, such as ease of raising funds, cheaper access to capital markets, speed and lower cost of company formation, and access to reliable legal jurisdictions (THE ECONOMIST, 2012). For instance, on paper, the British Virgin Islands ranks as the second-largest investor in China after Hong Kong (THE ECONOMIST, 2013b). The end result is that there may be little connection between where economic activity takes place and where the profits 
are registered. This has enormous implications for understanding firm behavior and strategies as part of global financial flows and networks. While Hong Kong is commonly viewed as a prominent world city and key IFC in Asia, the British Virgin Islands and other OJs are often overlooked when examining key actors and territories in global finance. Moreover, the division between onshore and offshore is not always clear cut and hides other processes at work. On the one hand, there is the increasing popularity of so-called 'midshore' finance centres, such as Singapore and Hong Kong, that combine offshore advantages (low taxes, secrecy) with onshore traits (strong legal systems, double taxation treaties, sophisticated financial markets); on the other hand, some onshore jurisdictions (e.g. Delaware, Miami) could be more lax than offshore ones (THE ECONOMIST, 2013a, 2013c). Given the importance of OJs in terms of how much they account for global financial activity and their considerable influence on corporate behavior, we have incorporated OJs alongside WCs as important territories in a GFN framework.

In this section, we have touched on some key contributions of financial geography research that has thus far largely centered on the development of IFCs and inter-city networks, and the field of financialisation. In conceptualizing an analytical framework for global finance, we argue for an expanded category of ABS that includes banking and financial institutions as well as accounting, law, business consultancy and related business services, due to their pivotal role in facilitating and enabling the work of finance and global production, often redefining landscapes of possibilities that have strong implications for regional development. WCs are certainly important 'command and control centres' and have featured prominently in both the financial geography literature and in GPN studies. Meanwhile, OJs are gaining increasing recognition (or perhaps notoriety) for (re)shaping the territorialities of financial flows and governance. As such, we argue that the roles of OJs and ABS need to be incorporated into a financial geography framework in order to fully appreciate the scope and magnitude of FDI, how financial instruments and entities are being used, and for what purposes. This nexus of WCs, ABS, and OJs is shown in Figure 1 as encapsulating the key GFN actors and territories. While ABS firms are key actors in shaping the flows of global finance, their work is enabled through a network of WCs, whose very economic structures and roles are in turn dependent upon the activities of ABS. At the same time, the creative capacities of ABS firms in seeking new methods and sources of profits have created new spatialities of finance in the form of OJs, which have in turn became more important to the business strategies of ABS firms and their global clients. WCs, ABS and OJs therefore articulate with one another to mobilize global flows of capital, channel them to (or through) specific places, and also shape the behavior of all firms in their pursuit of profits. Instead of treating global finance as just another type of GPN, we argue that it constitutes a distinctive GFN as it consists of specific actors and 
territories that tend to be undervalorized in much of the GPN literature, but which are important in explaining global patterns and flows of value creation and capture.

\section{Intersecting GFNs and GPNs}

In the previous section we delimited the defining characteristics of GFNs and their undoubted significance as a powerful form of global economic formation. GFNs, we have argued, are constituted by the articulation of ABS firms both within, and across, two particular types of territories, namely WCs and OJs. The second step in our argument is to assert that there is a pressing need to think about how GFNs intersect with the widely studied global production structures of the 'real' economy, which here we understand as GPNs ${ }^{\mathrm{iii}}$. As we will argue, this is important on two levels. First, finance is fundamental to all the economic activities that constitute GPNs. We need to know more about the financial dimensions of the complex multi-actor networks that underpin the production of goods and services within the global economy. Put another way, GPN analysis tends to focus on a world economy that produces approximately $\$ 70$ trillion worth of goods and services a year, but says much less about the points of contact with a financial system handling hundreds of trillions of dollars annually in financial assets, derivatives and other instruments. Second, and perhaps more importantly, the relative neglect of finance within the GPN literature means that it overlooked an increasingly important driver of GPN structures and strategies, namely the financial narratives, logics and rationalities circulating within and beyond GFNs. In a study of over 43,000 TNCs, VITALI et al. (2011) established that a core group of just 147 TNCs has almost 40 percent control over the economic value of TNCs in the world. It is all the more startling that $3 / 4$ of this core group are financial institutions, which points to the power of finance within the global network of corporations.

Our task in this section, therefore, is to think about different ways of framing the intersections of GFNs and GPNs and the wider implications of those intersections. Figure 1 seeks to capture the intersections in broad schematic terms, and builds upon previous representations of the 'ABS-offshore nexus' (WÓJCIK, 2013b, Figure 2) and the 'strategic coupling' of GPNs and regional economies (COE et al., 2004, Figure 1). In the former, the notion of the GFN was indicated through the interplay of ABS firms, WCs and OJs; in the latter, regional development was portrayed as being driven by the institutionally-mediated interface of GPN structures and regional assets. Figure 1 is intended to be suggestive of the overlaps of these two analytically distinct, yet interconnected formations. It is striving towards conceptualising an integrated global economic system encompassing both financial and production networks. Three points in particular are worth making. First, we must recognise that relationships between GPN lead actors and regional economies are mediated by ABS firms in addition 
to non-firm institutional structures. Second, the figure draws attention to the different kinds of territories that are connected into the global economic system, namely WCs and OJs in addition to 'production' regions. While they are separated here for analytical purposes, it is important to note that in reality the three types of territory identified may overlap in particular places. Singapore, for instance, is simultaneously a WC with a strong presence of corporate headquarters and ABS firms, an OJ with low taxation and financial secrecy, and remains an important production location in many global industries, for instance electronics and petrochemicals. Third, and as noted in COE et al. (2004), the institutional forces shaping the firm network/territory interface are multi-scalar in nature, and range from regionallyspecific factors up to the locally-experienced influence of national and international frameworks (e.g. WTO regulations, international accounting standards etc.). Overall, such as schema can only ever be suggestive at best; in what follows we seek to add more flesh to these bare bones in two stages.

\subsection{Financing GPNs}

Our starting point is to make the simple assertion that we need to know more about how the constituent activities of GPNs are financed. In 2003, POLLARD (p. 430) opined that 'firm finance is something of a "black box" in economic geography, a largely taken-for-granted aspect of production'. Some notable exceptions included CLARK and WRIGLEY's $(1995,1997)$ studies on how firms managed their sunk costs from a geographical perspective, research detailing the uneven geographies of venture capital (e.g. MASON and HARRISON, 1999; 2002; ZOOK, 2002), and work on retail internationalization where an interest in corporate finance was discernible (WRIGLEY, 1999; WRIGLEY and CURRAH, 2003). Remarkably, ten years on, her observation still largely holds true. While work on venture capital has continued (e.g. MARTIN et al., 2005; WRAY et al., 2011), there remains limited research on firm finance and its impact on firm behaviour, governance and strategy. Pollard diagnosed that this blindspot is linked to the two dominant theoretical approaches to firms within economic geography (and beyond): neoclassical economics tends to see finance as evenly distributed across space, while political economy prioritizes productive parts of the economy without exploring the connections to financial circuits. The same applies to the GPN literature and the cognate work on global commodity/value chains to which it is related; drawing on similar traditions (though leaning more towards political economy than economics), finance is a startling gap in this otherwise rich and multi-faceted literature. For example, in BAIR's 2009 edited volume entitled Frontiers of Commodity Chain Research, finance does not even feature in the index. In a recent overview of the GPN literature, one of us observed that 'a persistent and certainly valid critique of GPN research has been that it has underplayed the role of financial capital and the financial sector in shaping the configuration of global production systems' (COE, 2012, p. 392). 
We want to make three observations in this context. First, it is clear that much more research is needed on how the constituent firms within GPNs fund their activities. While the key global players that drive the networks in governance terms may be an obvious place to start, the subcontracted nature of many GPNs means that the funding of a whole range of specialized suppliers of different sizes may be equally important to the operation of the GPN as a whole. This goes beyond simply shedding light on a currently neglected area of corporate activity. Rather, we need to understand how the search for funding, and the conditions that are imposed in accessing that funding, affect corporate strategy in fundamental ways and, in turn, shape the geography of firm activities. For instance, when raising money from external sources through debt or equity ${ }^{\text {iv }}$, firms are exposed to varied forms of scrutiny and influence from different groups of financial institutions. Through such channels, "finance thus affects "corporate geographies" and the geographical structure of the economic landscape' (PRYKE, 2011, p. 294). In GPN research, it is implicit that funds are transferred from buyers to suppliers through the web of relationships that constitute the network. What is almost entirely missing, however, is an appreciation of the external funding environments of network participants and how they shape their ability to sustain participation in, and capture value from, the wider system.

Second, the nature of the external funding environment has shifted dramatically in recent times. POLLARD's (2003) piece was focused on small firm finance, and the interpersonal and geographical underpinnings of financial networks. Similarly, the venture capital research has tended to focus on the regional and/or national context of finance. The broad literatures on transnational corporations (e.g. DOREMUS et al., 1998), and varieties of capitalism/business systems (e.g. WHITLEY, 2001) in turn reflect how the home country financial environment shapes the globalization strategies of firms ${ }^{v}$. Our contention is that this link between home economy and the sourcing of finance, central to all these strands of work, has started to break down in important ways as large focal firms in GPNs increasingly operating within a global financial environment (see CLARK and WÓJCIK, 2007), or, in our terminology, within GFNs. This of course impacts on the firms themselves and how they seek to construct and influence the wider GPN. In studying how global corporations have internationalized their financial and governance structures, MORGAN (2001) finds that foreign ownership of shares and the role of institutional fund-owners have powerful impacts. Accessing capital from overseas shapes the 'transnational social space' of the MNC, for instance in terms of the effort that goes into managing the links between headquarters and financial centres, and the time spent managing expectations about shareholder value in different territories. Multiple listings may necessitate a move towards more transparent accounts and international standards thereof. Firms may have to break down and demarcate figures more clearly, there may be pressure to achieve a common rate of return across divisions, and 
links between different elements of the business may need to be justified. We shall return to these ideas in the next subsection, but for now the key point is that the key players in GPNs operate within an increasingly global funding environment, and shape the geography of their activities in order to maximize the benefits of that environment.

Third, GFN actors play a central role in the actual construction of GPN structures. Much work in the GPN tradition focuses on the operation of the network once it is established as opposed to the processes through which the transnational connections are forged. Closer scrutiny of those activities, we argue, would bring the entanglements of GFNs and GPNs once again into view. Finance in particular is important here; 'the decisions of financiers exert an extraordinarily powerful influence, not only in "lubricating" production circuits but also in shaping them through their evaluative decisions on what (and where) to invest in order to gain the highest (and sometimes the quickest) return' (DICKEN, 2011, p. 58). Accessing the funding necessary to enable GPN connections may be dependent on the assessment of GFN actors as to the likely profitability of those ventures. This is one reason why OJs have become increasingly popular in channeling FDI and corporate earnings in order to maximize profits and other benefits (THE ECONOMIST, 2013b). Moreover, a variety of other ABS firms, most notably legal services and management consultants, are heavily involved when a GPN focal firm seeks to establish operations in a host economy or, more likely, forge contractual relations with a company in a different national territory. Firms will almost certainly seek external help in terms of interpreting different country requirements for accounting, legal entities, local incorporation and the like. There is by a now a rich, 20 year old literature on ABS and the specialized and strategic contributions they make to national economies (e.g. WOOD, 1991), as well as their own internal globalization dynamics (e.g. TAYLOR et al., 2004). However, their active role in the building of global production structures is far less well-studied; GFNs are integral to the very creation of TNCs and GPNs ${ }^{\text {vi }}$. The key spaces of GFNs are central here; OJs are designed to meet the investment needs of TNCs and indeed are out of reach of small and medium-sized enterprises. In this way, OJs offer a competitive advantage to corporate actors seeking to construct global operations. Overall, much more research is needed to reveal how both the scope and realization of the investment strategies of firms within GPNs are defined and delineated by GFN actors.

\subsection{Financializing GPNs}

A second way of conceptualising the intersections of GFNs and GPNs is to go beyond understanding finance as simply a necessary input to all GPN activities to exploring the ways in which financial logics increasingly determine the very nature and operation of GPNs. In other words, we can consider the 
ways in which GPNs are increasingly becoming financialized. Financialization in this context can be understood as a process through which the financial sector and financial markets come to assume a dominant position within the wider economy and society (see FRENCH et al., 2011; and PIKE and POLLARD, 2010, for geographical overviews). Existing studies range from how the finance sector dominates national political economies (BLACKBURN, 2006; DORE, 2008), to how firm strategies and management are increasingly beholden to the logics of finance (WILLIAMS, 2000; FROUD et al., 2002; HO, 2009; KRIPPNER, 2005), and the ways in which households and individuals are tied into increasingly complicated relationships with the international financial system (MARTIN, 2002; LANGLEY, 2006; FRENCH and KNEALE, 2012). However, direct engagements between this increasingly rich literature and studies of GPNs have remained few and far between. In the context of our argument, financialization speaks to the ways in which TNCs and wider GPNs are increasingly controlled, monitored and disciplined through financial markets via notions such as shareholder value, calculations of risk, and market perception of mergers and acquisitions. As PRYKE (2011) describes, the key vectors of this financial power are ABS firms embedded in GFNs, most notably ratings agencies and sector analysts. The latter, for example, act as mediators between corporations and financial markets. The result is that key corporate actors within GPNs - i.e. lead firms but also a wide range of supplier firms which may often be large, publicly listed companies in their own right - not only have to organize processes to please consumers in the product market, 'they must now also satisfy professional funds managers and meet the expectations of the capital market' (WILLIAMS, 2000, p. 6) ${ }^{\mathrm{vii}}$.

The rise of the doctrine of shareholder value is seen as central to these dynamics (GIBBON and PONTE, 2005). In recent times, corporate equities have generally seen rising values and there have been volatile changes in ownership structure. Both are determined by how financial markets assess corporate performance through financial metrics, most notably the return on capital employed (ROCE for short). These narratives of 'capital structure' become central to a firm's ability to raise funds: higher ROCE rates mean higher value for equities and more shareholder value that can be released by selling those equities (GIBBON and PONTE, 2005). This logic is argued to lie behind the successive waves of corporate restructuring and downsizing of the past three decades (LAZONICK and O'SULLIVAN, 2000). Mutual funds and pensions funds, for example, hold an ever increasing proportion of equity in the world's corporations; this equity is traded in a small number of financial centres (WCs integral to the GFN), which in turn drives consolidation via mergers and acquisitions as firms seek financial market visibility and presence through increased scale. 'Knowing the financial narrative, then, is critical to knowing the geographies of accumulation and distribution pursued by the corporations' (O’NEILL, 2006, p. 139). 
It is important to recognise that there is no simple direct translation from ROCE measures to particular corporate strategies, however. As GIBBON and PONTE (2005: 13) describe '...the shareholder value doctrine is translated into corporate decision making only via internally contested processes that usually lead to some modifications' (see also FROUD et al., 2006). There are, for instance, a growing range of sectoral studies that unpack how financial logics are penetrating different industries such as the UK clothing retailers (GIBBON, 2002), auto manufacturing (KÄDTLER and SPERLING, 2002; FROUD et al. 2002) and law firms (FAULCONBRIDGE and MUZIO, 2009). Ultimately, corporate culture will come into play and firm-level factors will determine the precise outcome of external financial logics. In O'NEILL's (2006) case study of the Australian mining giant BHP Billiton, he diagnosed three outcomes of financial management narratives: the creation of new organizational structures, the creation of new management devices, and the creation of regulatory and performance standards within the wider financial community. MUELLERLEILE (2009), in turn, offers an account of the relocation of Boeing's corporate headquarters from Puget Sound near Seattle to Chicago in 2001; the headquarters in Chicago would allow firm to align itself with international financial markets, rather than being driven by engineering culture in Washington State. Moreover, WÓJCIK (2011) shows that this alignment is systematic, as corporate headquarters converge geographically with the securities industry, highlighting the continued significance of WCs as corporate decision-making centres, contrary to SASSEN's (1991) global city hypothesis.

These discourses are also geographically variable and intersect with different varieties of capitalism. For example, financialization is generally seen to be more advanced in 'neoliberal' economies such as the US and the UK. At the same time, however, a dynamic perspective is required, as demonstrated by VITOLS' (2002) analysis of how financialization logics were gaining strength in the German pharmaceuticals sector. Variegated capitalism, then, needs to be brought back into the picture (PECK and THEODORE, 2007; DIXON, 2010). JOHAL and LEAVER (2007), for instance, undertook a comparative analysis of the financial performance of leading French, UK and US firms over the period 1987-2005, finding that the French firms were relatively unprofitable in terms of ROCE and ROS (return on sales) measures, in part due to the nature of the national social settlement in France. During the study period, however, French firms were also using funds raised in global capital markets to internationalize vigorously, consolidating sales and profits in liberal economies such as the UK and US in order to cross-subsidize the social settlement in their home market (a similar argument can be made about the profits made by German firms in central and eastern Europe; see CLARK and WÓJCIK, 2007). 
What is urgently needed, however, are more studies that clearly connect financialization processes to processes of GPN creation, reconfiguration and governance. There are a few waymarkers in this regard. GIBBON (2002) offered one of the first analyses to look at the interconnections between financialization and global sourcing strategies, through the lens of the UK clothing sector. He found that increasing engagement with financial markets was leading to the externalization of manufacturing activity, a focus on fewer high volume suppliers, and intensified auditing and monitoring of supply networks. PALPACUER (2008), in turn, diagnosed that these dynamics were reducing the development potential for developing country localities enrolled into GPNs as price pressure and risk are passed down the system. MILBERG (2008) further delineates the symbiotic relations between financialization and the formation of GPNs as firms disintegrate production vertically and internationally in order to maintain profits and shareholder value. He uses statistical analysis to demonstrate the mutually reinforcing connections between financialization and the offshoring of production, and the 'leakage' of capital from sectoral systems into financial vehicles as firms seek to raise shareholder value rather than invest in productive assets (MILBERG, 2008; MILBERG and WINKLER, 2010). Finally, BAUD and DURAND (2012) tackle the conundrum of how leading retailers have managed to increase returns on equity in a period when their home market conditions have become increasingly tough. Their nuanced analysis demonstrates the intertwining strategies of globalization and financialization of assets, but also practices of 'working capital management' whereby retailers use their market power to extract concessions from suppliers and workers.

It is clear that the implications of financialization extend well beyond the GFN as 'more and more non-financial (e.g. manufacturing) firms are now driven by motives of financialization' (DICKEN, 2011, p. 58). Interestingly, these entanglements of GFNs and GPNs have for some time now been blurring the boundaries between 'financial' and 'non-financial' actors within the global economy. It is a moot point as to whether focal firms within GPNs such as GlaxoSmithKline, Ford and General Electric are productive or finance firms (FROUD et al., 2006). Another significant lacuna in the GPN literature is, therefore, the ways in which GPN actors (a) use the GFN to accrue and circulate the value created from their productive activities and (b) behave as financial actors by managing these activities themselves as opposed to through ABS firms. While it has long been recognised that TNCs use internal accounting practices such as transfer pricing to reduce their tax burden, the use of OJs for this purpose has become ever-more prevalent (and problematic for cash-strapped governments) (BBC NEWS, 2012). The financial arms of large corporations are also engaging as GFN actors in their own right, mobilizing investment vehicles and hedging currency, for instance, as part of their wider accumulation strategies. As non-financial firms accrue financial assets, their reliance on judicious use of OJs also rises. Given the 
scant discussion so far, there is clearly scope for examining how the value captured from production processes is enhanced and moved across space through the structures of the GFN.

\section{$4 \quad$ Measuring and tracking value in GPNs}

Having distilled the concept of the GFN and its critical intersections with GPNs, in this section we present some initial ideas on how these intersections can be operationalized in terms of data and methods. To achieve that goal we will move through different parts of Figure 1, starting with GPNs and regions, through $\mathrm{ABS}$ and $\mathrm{WCs}$, to $\mathrm{OJs}$, focusing on the problem of measuring value and its geographical distribution in GPNs. The difficulty of tackling this issue empirically has long been recognized (HADJIMICHALIS, 1984), but we hope to show that some progress can be made with a combination of quantitative and qualitative research at multiple scales of analysis - from country, through sector and company, to product level. This can be done through analyzing data from corporate accounting, macro accounting and the practices of ABS firms. We also suggest that integrating finance into GPNs requires positivist as well as normative and activist research.

The first underused source of data on stocks and flows of focal firms in GPNs lies in financial reports: balance sheets presenting a snapshot of corporate assets and their sources of financing; income statements focused on costs, revenues and profits; and cash flow statements presenting flows of money in operating, investment, and financing activities. Sources of financing can be assessed based on the balance sheet, showing the stocks of equity and debt, while their flows (including new issues of equity and debt, share buybacks and debt repayments) are shown in cash flow statements. Further details of fundraising events, including projects towards which new funds are directed, can be gleaned from the descriptive parts of annual reports, as well as prospectuses published for equity and bond issues. The identity of major shareholders can be found in corporate databases (e.g. Orbis, Amadeus or Fame) and annual reports, which may also offer data on major creditors. Information on the sources of corporate funding, including corporate ownership networks, can then be related to different aspects of corporate behavior and strategy, such as the scale and geographical scope of activity, supply and distribution networks, labour practices or environmental impacts (WRIGLEY, 1999; CLARK et al., 2004). This can be done through single case studies, comparative case studies or cross-sectional analysis of large samples of companies. With data aggregated at the level of subnational regions, insight into equity funding and ownership would complement the tradition of research in regional studies focused on the impact of bank lending patterns on regional development (DE GUEVARA and MAUDOS, 2009). While detailed financial reports are available for publicly traded companies only, they number tens of thousands worldwide, and represent a large share of corporate activity. 
In addition to sources of funding, corporate accounting offers data on various aspects of financialisation. One of the most popular indicators of corporate financialisation, and the primacy of shareholder value in corporate strategy, is the ratio of dividend and stock buyouts to net profits (FROUD et al., 2006). When the latter figure is related to wages and salaries, it can be used to measure the distribution of value between capital and labour (LAZONICK and O'SULLIVAN, 2000). Financialisation of non-financial companies can be measured with the ratio of financial income to total income or the holdings of financial assets to total assets (KRIPPNER, 2005; STOCKHAMMER, 2004). In addition to these measures, financialisation studies have also utilized qualitative insights from case studies and discourse analysis (see ERTURK et al., 2008). The challenge from the perspective of GPN research, however, is to combine such modes of analysis with emphasis on regional development outcomes, rather than studying financialisation for its own sake. As noted earlier, one such study shows that higher levels of financialisation in the US corporate sector are associated with more offshoring (MILBERG and WINKLER, 2010; MILBERG, 2008). The possible explanation is that offshoring lowers input prices and pressure on reinvestment of profits, thus helping to maintain profit margins and the allocation of profits to shareholders. In another study based on corporate interviews and reports evaluating closure options, PIKE (2006) shows how the shareholder value ideology contributed to the closure of the Vaux brewery in Sunderland, UK. Information on corporate divestment through sale to third parties may be obtained, for example, from Acquisitions Monthly of Thomson Reuters and on management buy-outs from the Centre for Management Buy-Out Research database (HAYNES et al., 2003).

The potential contribution of corporate accounting to GPN research lies also in accounting identities - relationships between different variables that hold true by definition, irrespective of the value of the variables. One such identity - the Du Pont method - presents the profitability of a company with the following equation (WHITE et al., 2003):

$$
\text { Net Profit/Equity }=\text { Net Profit } / \text { Revenues } * \text { Revenues } / \text { Assets } * \text { Assets } / \text { Equity }
$$

This offers a tool for analyzing the basics of a corporate strategy driven by the maximization of return on investment for its owners (the net profit/equity ratio on the left-hand side). The ratios on the righthand side represent net profit margin, turnover, and the extent to which a company funds itself with debt in relation to equity, also referred to as financial leverage, respectively. Focus on net profit margin is associated with a high value-low volume strategy, with a company maximizing its profit on each unit of sales. Focusing on turnover entails a low value-high volume strategy, where a company maximizes the sales volume, while realizing a low profit on each unit of sales. The leverage ratio, in turn, accounts for 
the sources of funding. A company can thus improve the return on investment for its owners by improving the quality of its products, the turnover of assets, or through judicious use of credit. Taken to the extreme, however, maximizing net profits over equity may result in tax evasion and aggressive tax avoidance, the suppression of wages, the maximization of trading for the sake of trading, and reckless

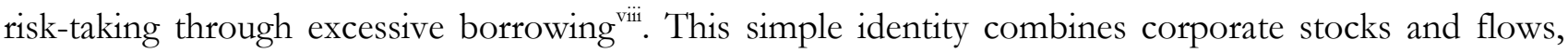
influenced by a mix of the production, marketing and financial activities of a corporation. It also shows that legal, accounting, and financial concepts and practices are basic considerations in corporate strategy, reminding us of the role of the ABS and their expertise in the life of corporations. Finally, the identity reminds us that the distribution of profits in GPNs needs to be analysed in relation to capital employed in the generation of profits. Using an example from DEDRICK et al. (2009), while Apple may capture most profit from iPod production in absolute terms, its value capture may look less impressive when related to its equity.

The value of corporate financial reports for studying GPNs at the level of individual products or commodities is limited. Both the US Generally Accepted Accounting Principles and the International Financial Reporting Standards, applied in more than 100 countries including the EU, require companies to break down their consolidated financial reports by operating segment i.e. a component of the company that engages in business activities from which it may earn revenues and incur expenses, and whose operating results are regularly reviewed by the company's chief operating decision maker (ROBERTS, 2010). Operating segments may represent product lines or geographical areas. In practice, however, segment reporting is not enforced, and companies tend to disclose financial data for broad aggregations only, with oil companies, for example, using the categories of upstream, downstream, and chemical activities. One way around this problem is to use so-called 'teardown' reports produced by market research companies that list components and inputs of different products along with their costs and suppliers. Combining this information with data on wholesale prices of end products makes it possible to calculate gross margins and their distribution in the GPN. Using this method, DEDRICK et al. $(2009,2011)$ for example, analyze the distribution of financial value from innovation in the global supply chains of iPods, notebook computers and mobile phones.

An alternative and complementary method to using corporate reporting is to start with financial data on the collective financial footprint of the corporate sector by regions. This leads us to the use of flow-of-funds or stock-flow consistent models (here referred to as macro-accounting) that focus on the stocks and flows in key economic sectors: corporate sector, households, government, and finance, insurance and real estate (FIRE). The model can cover a whole national economy or individual industries and regions. A typical macro-accounting model consists of a table showing flows of funds 
between sectors, and a table showing the balance sheet of each, with all variables and figures related to each other through a series of macro-accounting identities (GODLEY and LAVOIE, 2007). Macroaccounting models are rooted in post-Keynesian economics, an important alternative to both neoclassical and Marxian economics but marginalized in the last few decades. What distinguishes these models is the focus on the financial sector and its impact on the economy of industries, regions and countries. Rather than being a mere intermediary channeling funds from savers to borrowers, the financial sector is seen as having a fundamental impact on economic growth and stability, mainly through the creation of credit. With this focus on finance, macro-accounting models anticipated the recent global financial crisis better than the equilibrium models of neo-classical economics, which are ubiquitous in mainstream policy circles. They turned out 'to be the shared mindset of a large subset of those analysts who worried about a credit-cum-debt crisis followed by a recession, before the policy and academic establishment did' (BEZEMER, 2010, 676).

Just as corporate accounting reminds us of the significance of liabilities for understanding corporate behavior, macro-accounting reminds us that regional balance sheets have two sides as well. While conventional economic geography focuses on (tangible and intangible) assets, and regional inputoutput analysis focuses on purchases and sales between different sectors, macro-accounting models put equal emphasis on stocks/flows and assets/liabilities. Their application helps analyze flows of credit between sectors and regions, the level of leverage of industries and regions, and the build-up of asset price bubbles, contributing to an early warning system with regard to financial stability. For example, consider that in 2006 net profits in the US banking sector were estimated at US $\$ 400$ billion; assuming that a quarter came from foreign operations still left profits after tax of US\$3000 per US household. An economy in which each household effectively contributes US\$250 a month to banks is clearly not sustainable. Macro-accounting thus highlights the circular nature of the economy. Revenues and profits have to come from someone and somewhere; they are not generated out of thin air. At present only a subset of advanced economies collect macro-accounting data, but even the limited amount of data available represents significant potential (BARWELL and BURROWS, 2011).

Beyond corporate and macro-accounting, financially-informed GPN research requires insight into the practices of ABS, particularly their interaction with lead firms in GPNs. This is tricky as both TNCs and the large ABS firms serving them operate as extensive networks. When one global company interacts with another global company, it is difficult to pinpoint the impact of the interaction on urban and regional development. This calls for more case studies that investigate the spatial division of labour in the provider-client and provider-provider relationships among ABS firms and other TNCs. These could focus on major corporate projects such as equity or debt issues, entry into new markets, mergers 
and acquisitions, or corporate divestment projects. Building on the type of research that characterizes the Globalisation and World Cities (GaWC) research group (see: http://www.lboro.ac.uk/gawc/), based mostly on the study of ABS office networks, such case studies could uncover actual flows of transactions, fees, as well as stocks of employment and expertise in particular cities as ABS centres. In addition, they would help unveil the influence of ABS firms on corporate behavior, and consequently its footprint. Take, for example, the initial public offering of China Mobile, the world's largest mobile phone operator. WALTER and HOWIE's (2011) study reveals how foreign ABS firms were instrumental in recommending and executing the consolidation of the Chinese mobile telecommunications sector as part of the IPO process, and in transforming China Mobile into the country's first 'national champion' ix . In their words 'the New China of the twenty-first century is a creation of the Goldman Sachs and Linklaters \& Paines of the world, just as surely as the Cultural Revolution flowed from Chairman Mao's Little Red Book' (p. 159).

From the methodological perspective, OJs probably represent the most challenging element of the GFN. Economic geography has in the recent past offered rich case studies of offshore financial centres and tax havens (ROBERTS, 1995; HUDSON, 2000; WARF, 2002), but this research seems to have lost momentum in the 2000s. In order to revive research on OJs as a vital component of the GFN framework, we propose greater emphasis on ABS firms as they intermediate between OJs and their customers, with a particular focus on the offshore activities of TNCs and interconnections with WCs as key nodes of these relationships. To advance this agenda, one can examine the legal structures of companies, for example, as presented in corporate annual reports or securities issuance prospectuses. Legal entities registered in OJs are typically majority- or fully-owned by other companies, obliging the latter to disclose their existence, even if their functions and financial details remain opaque. China Mobile, for example, is registered in Hong Kong, majority-owned by a company in the British Virgin Islands, and controls regional Chinese companies via shell companies also registered in the British Virgin Islands. Such secondary data could be combined with corporate interviews enquiring about the genesis and functions of offshore entities. Other strategies would involve investigation of tax advisory departments in ABS firms (with the Big Four in the lead) and the specialized offshore industry (including companies such as OCRA Worldwide), with the City of London serving as their global hub (WAINWRIGHT, 2011). Finally, there is new data available from the IMF on foreign direct and portfolio investment, which offers some coverage of OJs, thus opening up opportunities to analyze factors that shape stocks and flows of offshore finance, and interactions between OJs and other economies. 
Adding another challenge, but also injecting a dash of optimism into our review, we should point to an initiative that offers major potential for research integrating finance into GPNs. Country-byCountry-Reporting (CBCR), conceived by Richard Murphy, a London-based tax advisor and campaigner, and supported by a number of civil society organizations with the Tax Justice Network in the lead, would oblige corporations to publish separate financial statements for each country in which they operate, including figures on intra-company flows and stocks. CBCR is being introduced in the USA and the EU in a minimalistic form, restricted to payments between companies and governments in the extractive industry being disclosed on a country-by-country and project-by-project basis. Recent developments in the USA and the EU, however, might serve as a catalyst for a deeper and broader reform of corporate transparency. From the perspective of GPN research, CBCR would enhance the value of corporate accounting data, but also facilitate its comparison with that from macro-accounting, as well as shedding light on the position of OJs within GPNs. ABS firms largely oppose CBCR, taking the side of the large corporations who pay for their services, which once again highlights their agency in GPNs (WÓJCIK, 2012).

\section{$5 \quad$ Towards a research agenda}

This paper has highlighted the potential for more work within the GPN tradition regarding the role of finance in the dynamics of the global economy and regional development. As such, our paper echoes and responds to more general calls for research bridging geographies of finance and geographies of production. A recent editorial in Economic Geography stressed that 'the geography of contemporary economies cannot be understood without understanding finance, for finance has simply become too important, and finance cannot be understood without attention to its intrinsic spatiality' (AOYAMA et al., 2011, 119). TAYLOR (2012) also highlights the study of corporate financing and financialisation, jurisdictional laxity, and transactional governance, including the workings of law and contracts, as key areas to be readdressed by economic geography.

In this agenda to integrate finance into the GPN approach, on the theoretical side, we proposed a GFN framework focusing on ABS, WCs and OJs, and highlighted the intersections of GFNs with GPNs. Taken together, GFNs and GPNs delimit the firm-territory nexus and expose a map of the world economy in which relationships between GPNs and regions (and their agents) are intermediated not only through formal and informal institutions, but also through ABS firms. As pointed out by Clark (1993), the globalisation of production, as captured in the GPN framework, represents increased financial risks for the firms involved, including foreign exchange risks, interest rate risks, commodity price risks, and contractual risks. The networked character of production - another focus of the GPN 
approach - aggravates the negative effects of funding shortages, since funding is needed to sustain not just an individual firm, but also the commitments and trust across the entire network. In an increasingly globalized and networked environment firms turn to ABS firms as experts in financial risk management. GFNs also reflect a map of the world economy in which world city-ness and offshore-ness bring dividends in terms of regional development, though they may accrue at the expense of regions unable to avail themselves of these attributes. Witness the increasing concentration of income and wealth in globally connected city-regions and growing disparities between them and the rest of their domestic economies (McCann and Acs, 2011). Meanwhile Liechtenstein, Luxembourg, Bermuda, Jersey, Guernsey, the Cayman Islands, Gibraltar, and Ireland are among the top 20 jurisdictions of the world according to GDP per capita, but how could we explain their economic development and prosperity without reference to offshore-ness? Relatedly, the examples of Singapore and Hong Kong - also in the top 20 - show that some places can combine both elements of WC and OJ in GFNs.

Our suggestions on data and methods for integrating finance into GPNs involve the use of corporate and macro-accounting, combined with qualitative research on corporate behavior and ABS firms as a major influence on this behavior. It is often said that 'accounting is the language of business' and there is certainly much to gain from more intensive use of accounting data, particularly for GFN and GPN research. While we believe that a quantitative approach is necessary to measure and track value in GPNs, a more sociological approach that uses economic practices as an empirical lens would also offer valuable and complementary insights (Jones and Murphy, 2011). Our agenda is both positivist and normative, including the need for engagement with heterodox economists, Post-Keynesians, and the promoters of CBCR. Arguably, the global financial crisis has created an unprecedented chance for geographers to join forces with other social scientists and social movements to support the creation of new sources of data and higher levels of corporate transparency. In so doing, we can also open up vital new insights into the forces shaping the wider production structures of the global economy.

To progress further, the agenda we have started to delineate here requires closer dialogue between financial geographers and geographers interested in the globalisation of production, with an explicit focus on explaining the creation, enhancement, and capture of value in and across space. The time for integrating finance into the GPN approach is ripe. The global financial crisis has reinvigorated demand for improved transparency of capital flows and stocks at both micro and macro levels. Civil society organizations, social movements, and some governments are calling for more geographicallyinformative corporate financial reporting. At the macro-level, certain economists and policy-makers are rediscovering the advantages of keeping track of national and regional stocks and flows of capital, as well as sources of financing and leverage, rather than relying on marginalist measures such as prices and rates 
of inflation and interest. To be sure, integrating finance into GPNs is a challenging task, but at stake is an opportunity to develop a common framework to understand the interplay and impacts of the two most important phenomena of the last 40 years - globalisation and financialisation. 
Figure 1. The Global Production and Financial Networks

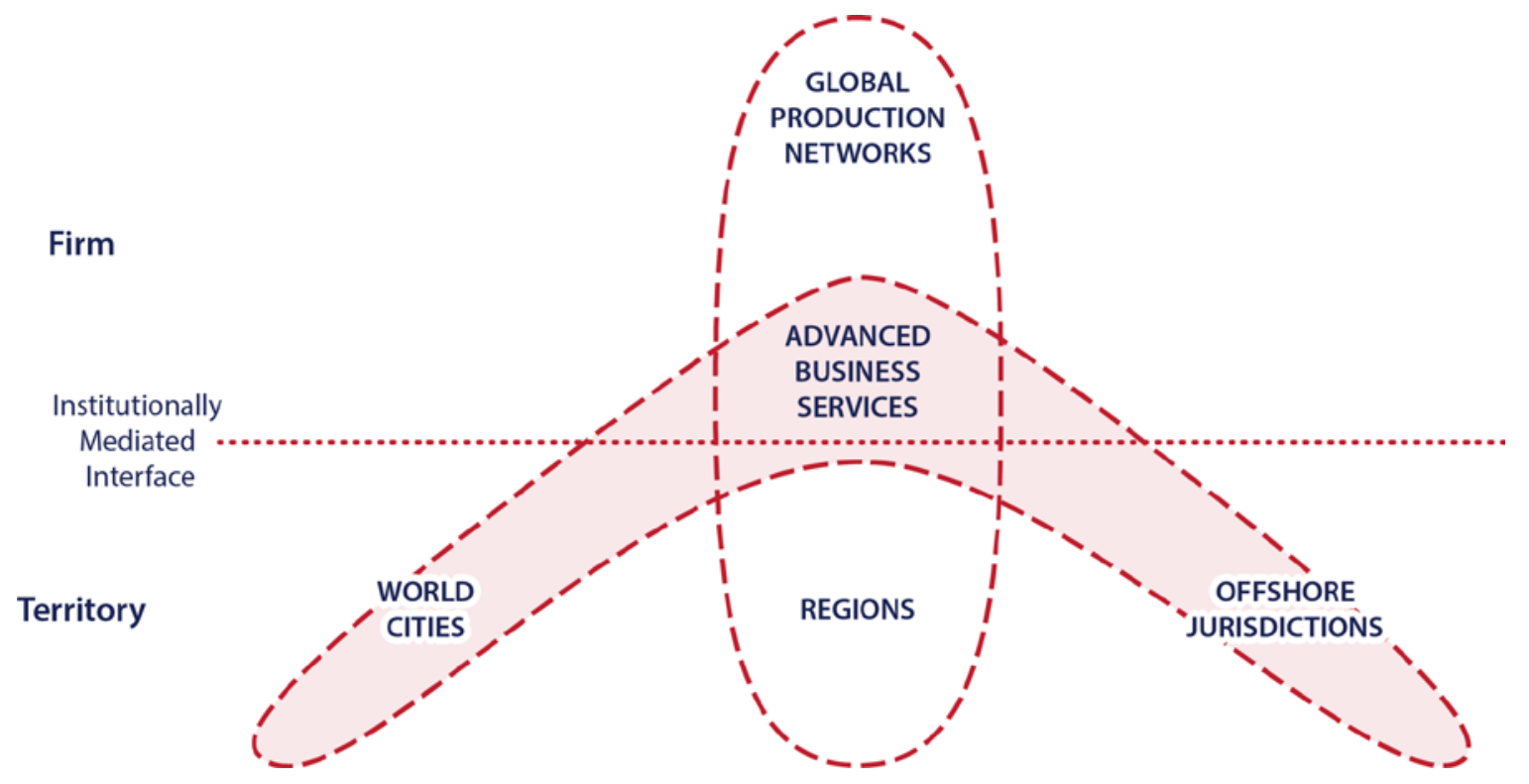

Source: Authors

\section{References}

AOYAMA, Y., BENNER, C., BERNDT, C., COE, N. M., ENGELEN, E., ESSLETZBICHLER, J., GLASSMAN, J., GLÜCKLER, J., GROTE, M., JONES, A., LEICHENKO, R., LESLIE, D., LINDNER, P., LORENZEN, M., MANSFIELD, B., MURPHY, J.T., POLLARD, J.S., POWER, D., STAM, E., WÓJCIK, D. and ZOOK, M. (2011) Emerging themes in economic geography: outcomes of the Economic Geography 2010 workshop, Economic Geography, 87, 111-126.

BAIR, J. (2009) Frontiers of commodity chain research, Stanford University Press, Stanford.

BARWELL, R. and BURROWS, O. (2011) Growing fragilities? Balance sheets in the Great Moderation. Financial Stability Paper No. 10 (April), London, Bank of England.

BASSENS, D., DERUDDER, B. and WITLOX, F. (2010) Searching for the Mecca of finance: Islamic financial services and the world city network, Area, 42, 35-46.

BAUD, C. and DURAND, C. (2012) Financialization, globalization and the making of profits by leading retailers, Socio-Economic Review, 10, 241-266.

BBC NEWS (2012) Tax paid by some global firms in UK 'an insult', 3 December 2012 (available at http://www.bbc.co.uk/news/business-20559791). 
BEAVERSTOCK, J. V., SMITH, R. J. and TAYLOR, P. J. (1999) A roster of world cities, Cities, 16, 445-458.

BEAVERSTOCK, J. V. 2004. 'Managing across borders': knowledge management and expatriation in professional service legal firms. Journal of Economic Geography, 4, 157-179.

BEAVERSTOCK, J. V. (2007) Transnational work: Global professional labour markets in professional service accounting firms, in BRYSON, J. R., DANIELS, P. W., HENRY, N. and POLLARD, J. (Eds.) Knowledge, Space, Economy, London, Routledge.

BEAVERSTOCK, J. V., HOYLER, M., PAIN, K. and TAYLOR, P. J. (2005) Demystifying the Euro in European financial centre relations: London and Frankfurt, 2000-2001, Journal of Contemporary European Studies, 13, 143-157.

BEZEMER, D.J. (2010) Understanding financial crisis through accounting models, Accounting, Organizations and Society, 35: 676-688.

BLACKBURN, R. (2006) Finance and the fourth dimension, New Left Review, 39, 39-70.

BRYSON, J. and DANIELS, P. W. (Eds.) (1998) Service Industries in the Global Economy, Cheltenham, Edward Elgar.

BRYSON, J. R. (2000) Spreading the message: management consultants and the shaping of economic geographies in time and space, in BRYSON, J. R., DANIELS, P. W., HENRY, N. and POLLARD, J. (Eds.) Knowledge, Space, Economy, London, Routledge.

BUDD, L. (1999) Globalisation and the crisis of territorial embeddedness of international financial markets, in MARTIN, R. (Ed.) Money and the Space Economy, New York, Wiley.

CLARK, G.L. (1993) Global interdependence and regional development: business linkages and corporate governance in a world of financial risk., Transactions of the Institute of British Geographers, 18, 309-325.

CLARK, G. L. (1999). The retreat of the state and the rise of pension fund capitalism, in MARTIN, R. (Ed.) Money and the Space Economy, Chichester, John Wiley \& Sons.

CLARK, G. L. and O'CONNOR, K. (1997) The informational content of financial products and the spatial structure of the global finance industry, in COX, K. R. (Ed.) Spaces of Globalisation: Reasserting the Power of the Local, New York, Guilford Press. 
CLARK, G. L. and WÓJCIK, D. (2007) The geography of finance: corporate governance in the global marketplace, Oxford, Oxford University Press. CLARK, G. L., PALASKAS, T., TRACEY, P., and TSAMPRA, M. (2004) Globalization and competitive strategy in Europe's vulnerable regions: firm, industry and country effects in labour-intensive industries, Regional Studies, 38, 1085-1100.

CLARK, G.L. and WRIGLEY, N. (1995) Sunk costs: a framework for economic geography, Transactions of the Institute of British Geography, 20, 204-223.

CLARK, G.L. and WRIGLEY, N. (1997) The spatial configuration of the firm and the management of sunk costs, Economic Geography, 73, 285-304.

COE, N. M. (2012) Geographies of production II: A global production network A-Z. Progress in Human Geography, 36, 389-402.

COE, N. M., DICKEN, P., and HESS, M. (2008) Global production networks: realizing the potential. Journal of Economic Geography, 8, 271-295.

COE, N.M., HESS, M., YEUNG, H.W.C., DICKEN, P. and HENDERSON, J. (2004) Globalizing regional development: a global production networks perspective, Transactions of the Institute of British Geographers, 29, 468-484.

CORBRIDGE, S. (1994) Bretton Woods revisited: hegemony, stability, and territory. Environment and planning $A$, 26, 1829-1859.

DE GUEVARA, J.F. and MAUDOS, J. (2009) Regional financial development and bank competition: Effects on firms' growth, Regional Studies, 43, 211-228.

DEDRICK, J., KRAEMER, K.L. and LINDEN, G. (2009) Who profits from innovation in global value chains? A study of the iPod and notebook PCs, Industrial and Corporate Change, 19, 81-116.

DEDRICK, J., KRAEMER, K.L. and LINDEN, G. (2011) The distribution of value in the mobile phone supply chain, Telecommunications Policy, 34, 505-521

DICKEN, P. (2011) Global shift: mapping the changing contours of the world economy, Sage, London.

DIXON, A. (2010) Variegated capitalism and the geography of finance, Progress in Human Geography, 35, 193-210.

DORE, R. (2008) Financialization of the global economy, Industrial and Corporate Change, 17, 1097-1112.

DOREMUS, P.N., KELLER, W.W., PAULY, L.W., and REICH, S. (1998) The myth of the global corporation, Princeton University Press, Princeton. 
ENGELEN, E. (2008) The case for financialization, Competition \& Change, 12, 111-119.

ERTURK, I., FROUD, J., LEAVER, A. and WILLIAMS, K. (Eds.) (2008) Financialization at work: Key texts and commentary, Abingdon, Routledge.

FAULCONBRIDGE, J. (2004) London and Frankfurt in Europe's evolving financial centre network, Area, 36, 235-244.

FAULCONBRIDGE, J. and MUZIO, D. (2009) The financialization of large law firms: situated discourses and practices of reorganization, Journal of Economic Geography, 9, 641-661.

FRENCH, S. and KNEALE, J. (2012) Speculating on careless lives: annuitising the biofinancial subject, Journal of Cultural Economy, 5, 391-406.

FRENCH, S., LEYSHON, A. and WAINWRIGHT, T. (2011) Financializing space: spacing financialisation, Progress in Human Geography, 35, 798-819.

FROUD, J., HASLAM, C., JOHAL, S. and WILLIAMS, K. (2002) Cars after financialisation: a case study in financial under-performance, constraints and consequences, Competition and Change, 6, 13-41.

FROUD, J., JOHAL, S. and WILLIAMS, K. (2002) Financialization and the coupon pool, Capital and Class, 78, 119-151.

FROUD, J., JOHAL, S., LEAVER, A. and WILLIAMS, K. (2006) Financialization and strategy: narrative and numbers, Routledge, Abingdon.

GIBBON, P. (2002) At the cutting edge? Financialisation and UK clothing retailers' global sourcing patterns and practices, Competition \&o Change, 6, 289-308.

GIBBON, P. and PONTE, S. (2005) Trading down: Africa, value chains, and the global economy, Temple University Press, Philadelphia.

GODLEY, W. and LAVOIE, M. (2007) Monetary Economics: An Integrated Approach to Credit, Money, Income, Production and Wealth, London, Palgrave/Macmillan.

HADJIMICHALIS, C. (1984) The geographical transfer of value: notes on spatiality of capitalism, Environment and Planning D: Society and Space, 2, 329-345.

HALDANE, A. and MAY, R. (2011) Systemic risk in banking ecosystems, Nature, 469, 351-355.

HALL, S. (2013) Geographies of money and finance III: financial circuits and the 'real economy', Progress in Human Geography, 37, 285-292. 
HAYNES, M., THOMPSON, S. and WRIGHT, M. (2003) The determinants of corporate divestment: evidence from a panel of UK firms, Journal of Economic Behavior and Organization, 52, 147-166.

HELLEINER, E. (1995) Explaining the globalisation of financial markets: Bringing the state back in Review of International Political Economy, 2, 315-341.

HENDERSON, J., DICKEN, P., HESS, M., COE, N.M., YEUNG, H.W.C. (2002) Global production networks and the analysis of economic development, Review of International Political Economy, 9, 436464.

HO, K. (2009) Liquidated: An ethonography of Wall Street, London, Duke University Press.

HUDSON, A (2000) Offshoreness, globalization and sovereignty: a postmodern geo-political economy? Transactions of the Institute of British Geographers, 25: 269-283.

JOHAL, S. and LEAVER, A. (2007) Is the stock market a disciplinary institution? French giant firms and the regime of accumulation, New Political Economy, 12, 349-367.

JONES, A. (2003) Management consultancy and banking in an era of globalisation, Basingstok, Hampshire, Palgrave Macmillan.

JONES, A. and MURPHY, J.T. (2011) Theorizing practice in economic geography: Foundations, challenges, and possibilities, Progress in Human Geography, 35, 366-392.

KÄDTLER, J. and SPERLING, H-J. (2002) The power of financial markets and the resilience of operations: arguments and evidence from the German car industry, Competition and Change, 6, 81-94.

KRIPPNER, G. (2005) The financialization of the American economy, Socio-Economic Review, 3, 173-208.

LAI, K. P. Y. (2006) 'Imagineering' Asian emerging markets: financial knowledge networks in the fund management industry, Geoforum, 37, 627-642.

LAI, K. P. Y. (2012) Differentiated markets: Shanghai, Beijing and Hong Kong in China's financial centre network, Urban Studies, 49, 1275-1296.

LANGLEY, P. (2006) The making of investor subjects in Anglo-American pensions, Environment and Planning D: Society and Space, 24, 919-934.

LANGLEY, P. 2008. The everyday life of global finance: Saving and borrowing in Anglo-America, Oxford, Oxford University Press.

LAOZONICK, B. and O'SULLIVAN, M. (2000) Maximising shareholder value: a new ideology of corporate governance, Economy and Society, 29, 13-35. 
LEYSHON, A. and THRIFT, N. (1997a) Money/space: Geographies of Monetary Transformation, New York, Routledge.

LEYSHON, A. and THRIFT, N. (1997b) Spatial financial flows and the growth of the modern city, International Social Science Journal, 49, 41-54.

LEYSHON, A. (1992) The transformation of regulatory order: Regulating the global economy and environment, Geoforum, 23, 249-267.

LEYSHON, A., BURTON, D., KNIGHTS, D., ALFEROFF, C. and SIGNORETTA, P. (2004)

Towards an ecology of retail financial services: understanding the persistence of door-to-door credit and insurance providers. Environment and Planning A, 36, 625-645.

MACKINNON, D. (2012) Beyond strategic coupling: reassessing the firm-region nexus in global production networks, Journal of Economic Geography, 12, 227-245.

MAJOR, T. (2000) VW faces criticism over fall in shares, Financial Times, 24 May.

MARTIN, R. (1999) Selling off the state: Privatisation, the equity market and the geographies of shareholder capitalism, in MARTIN, R. (Ed.) Money and the Space Economy, Chichester: John Wiley \& Sons.

MARTIN, R. (2002) The financialization of daily life, Philadelphia, Temple University Press.

MARTIN, R., BERNDT, C., KLAGGE, B. and SUNLEY, P. (2005) Spatial proximity effects and regional equity gaps in the venture capital market: evidence from Germany and the UK, Environment and Planning A, 37, 1207-1231.

MASON, C.M. and HARRISON, R.T. (1999) Financing entrepreneurship: venture capital and regional development, in R. MARTIN (Ed.) Money and the space economy, Wiley, Chichester.

MASON, C.M. and HARRISON, R.T. (2002) The geography of venture capital investments in the UK, Transactions of the Institute of British Geographers, 27, 427-451.

MAURER, B. (2008) Re-regulating offshore finance? Geography Compass, 2, 155-175.

MCCANN, P. and ACS, Z.J. (2011) Globalization: countries, cities and multinationals, Regional Studies, $45,17-32$.

MILBERG, W. (2008) Shifting sources and uses of profits: sustaining US financialization with global value chains, Economy and Society, 37, 420-51. 
MILBERG, W. and WINKLER, D. (2010) Financialisation and the dynamics of offshoring in the USA, Cambridge Journal of Economics, 34, 275-293.

MORGAN, G. (2001) The multinational firm: organizing across institutional and national divides, in G. MORGAN, P.H. KRISTENSEN and R. WHITLEY (Eds.) The multinational firm: organizing across institutional and national divides, Oxford University Press, Oxford.

MORGAN, G., KRISTENSEN, P.H., and WHITLEY, R. (Eds.) (2001) The multinational firm: organizing across institutional and national divides, Oxford University Press, Oxford.

MORGAN, G., WHITLEY, R. and MOEN, E. (Eds.) (2005) Changing capitalisms? Internationalization, institutional change, and systems of economic organization, Oxford University Press, Oxford.

MUELLERLEILE, C. (2009) Financialization takes off at Boeing, Journal of Economic Geography, 9, 663677.

O'NEILL, P. (2006) The corporation, shareholder value added, and the power of financial management narratives, in M. TAYLOR and P. OINAS (Eds.) Understanding the firm: spatial and organizational dimensions, Oxford University Press, Oxford.

PALPACUER, F. (2008) Bringing the social context back in: governance and wealth distribution in global commodity chains, Economy and Society, 37, 393-419.

PECK, J. and THEODORE, N. (2007) Variegated capitalism, Progress in Human Geography, 31, 731-772.

PIKE, A. (2006) 'Shareholder value' versus the regions: the closure of the Vaux brewery in Sunderland, Journal of Economic Geography, 6, 201-222.

PIKE, A. and POLLARD, J. (2010) Economic geographies of financialization. Economic Geography, 86, 29-51.

POLLARD, J. and SAMERS, M. (2011) Governing Islamic finance: territory, agency and the making of cosmopolitan financial geographies, Annals of the Association of American Geographers, DOI:10.1080/00045608.2011.628256.

POLLARD, J. S. (2003) Small firm finance and economic geography, Journal of Economic Geography, 3, 429-452.

PORTEOUS, D. J. (1999) The development of financial centres: Location, information externalities and path dependence, in MARTIN, R. (Ed.) Money and the Space Economy, Chichester: Wiley. 
PRYKE, M. (2011) Geographies of economic growth II: money and finance, in A. LEYSHON, R. LEE, L. McDOWELL and P. SUNLEY (Eds.) The Sage handbook of economic geography, Sage, London.

ROBERTS, S. (1995) Small place, big money: The Cayman Islands and the international financial system, Economic Geography, 71, 237-256.

ROBERTS, C.B. (2010) Segment reporting, in C. NOBES and R.B. PARKER (Eds.) Comparative International Accounting, Harlow: Pearson.

SASSEN, S. (1991) The Global City: London, New York, Tokyo, Princeton, NJ, Princeton University Press.

SASSEN, S. (2001) The Global City: London, New York, Tokyo, Princeton, NJ, Princeton University Press.

SMITH, A. (1776) The Wealth of Nations. Edited with an introduction and notes by A. Skinner. London, Penguin Books

SMITH, A. and SWAIN, A. (2010) The global economic crisis, Eastern Europe and the former Soviet Union: models of development and contradictions of internationalisation, Eurasian Geography and Ecnoomics, 51, 1-34.

STIGLITZ, J. E. (2010) Risk and global economic architecture: Why full financial integration may be undesirable, The American Economic Review, 100, 388-392.

STOCKHAMMER, E. (2004) Financialization and the slowdown of accumulation, Cambridge Journal of Economics, 28, 719-741.

TAYLOR, M. (2012) 'Island life': Basking in isolation, Dialogues in Human Geography, 2: 162-164.

TAYLOR, P.J., CATALANA, G. and WALKER, D. (2004) Multiple globalisations: regional, hierarchical and sectoral articulations of global business services through world cities, Service Industries Journal, 24, 63-81.

THE ECONOMIST (2012) Company formation: shells and shelves, 7 April.

THE ECONOMIST (2013a) Onshore financial centres: Not a palm tree in sight, 16 February.

THE ECONOMIST (2013b) Special report: Offshore finance, 16 February.

THE ECONOMIST (2013c) Switzerland and its rivals: Rise of the midshores, 16 February.

THRIFT, N. (1994) On the social and cultural determinants of international financial centres: the case of the City of London, in CORBRIDGE, S., MARTIN, R. L. and THRIFT, N. (Eds.) Money, Power and Space, Oxford, Blackwell. 
THRIFT, N. (1998) Always here and there: The City of London, in UNWIN, T. (Ed.) A European Geography, Harlow, Essex, Addison Wesley Longman.

VITALI, S., GLATTFELDER, J.B. and BATTISTON, S. (2011) The network of global corporate control, PLOS ONE 6(10), e25995. doi:10.1371/journal.pone.0025995.

VITOLS, S. (2002) Shareholder value, management culture and production regimes in the transformation of the German chemical-pharmaceutical industry, Competition and Change, 6, 309-325.

WAINWRIGHT, T. (2011) Tax doesn't have to be taxing: London's 'onshore' finance industry and the fiscal spaces of a global crisis, Environment and Planning A, 43, 1287-1304.

WALTER, C.E. and HOWIE, F.J.T. (2011) Red Capitalism: The fragile financial foundations of China's extraordinary rise, Wiley, New York.

WARF, B. (2002) Tailored for Panama: offshore banking at the crossroads of the Americas, Geografiska Annaler B, 84, 33-47.

WHITE, G.I., SONDHI, A.C., FRIED, D. (2003) The Analysis and Use of Financial Statements, Wiley, New York.

WHITLEY, R. (2001) How and why are international firms different? The consequences of crossborder managerial coordination for firm characteristics and behaviour, in G. MORGAN, P.H. KRSITENSEN and R. WHITLEY (Eds.), The multinational firm: organizing across institutional and national divides, Oxford University Press, Oxford.

WILLIAMS, K. (2000) From shareholder value to present-day capitalism, Economy and Society, 29, 1-12.

WÓJCIK, D. (2012) Accounting for Globalization: Evaluating the Effectiveness of Country-by-Country Reporting. Employment, Work and Finance Working Paper No. 12-08 (available at SSRN: http://ssrn.com/abstract=2163456).

WOJJCIK, D. (2011) Securitization and its footprint: the rise of the US securities industry centres 19982007, Journal of Economic Geography, 11, 925-947.

WÓJCIK, D. and BURGER, C. (2010). Listing BRICs: issuers from Brazil, Russia, India and China in New York, London and Luxembourg, Economic Geography, 86, 275-296.

WÓJCIK, D. (2013) The dark side of NY-LON: financial centres and the global financial crisis. Urban Studies, http://usj.sagepub.com/content/early/2013/02/05/0042098012474513.full.pdf. 
WÓJCIK, D. (2013b) Where governance fails: Advanced business services and the offshore world. Progress in Human Geography, 37, 330-347.

WÓJCIK, D. (2013c) ‘Capitalist tools in socialist hands’? China Mobile in the Global Financial Network. Employment, Work and Finance Working Paper No. 13-05 (available at SSRN: http://papers.ssrn.com/sol3/papers.cfm?abstract_id=2297372).

WÓJCIK, D., BEAVERSTOCK, J. V. and SIDAWAY, J. (2007) European financial geographies, Growth and Change, 38, 167-173.

WOOD, P. A. (1991) Flexible accumulation and the rise of business services, Transactions of the Institute of British Geographers, 16, 160-172.

WOOD, P. A. (2006) Urban development and knowledge-intensive business services: Too many unanswered questions? Growth and Change, 37, 335-361.

WRAY, F., MARSHALL, N. and POLLARD, J. (2011) Finance and local and regional economic development, in A. PIKE, A. RODRÍGUEZ-POSE and J. TOMANEY (Eds.) Handbook of local and regional development, Routledge, London.

WRIGLEY, N. (1999) Corporate finance, leveraged restructuring and the economic landscape: the LBO wave in US food retailing, in R. MARTIN (Ed.) Money and the space economy, Wiley, Chichester.

WRIGLEY, N. and CURRAH, A. (2003) The stresses of retail internationalization: lessons from Royal Ahold's experience in Latin America, International Review of Retail, Distribution and Consumer Research, $13,221-243$.

YEUNG, H.W.C. (2009) Regional development and the competitive dynamics of Global Production Networks: An East Asian perspective, Regional Studies, 43, 325-351.

ZOOK, M. (2002) Grounded capital: venture financing and the geography of the Internet industry, Journal of Economic Geography, 2, 151-177.

ZUKIN, S. (1992) The city as a landscape of power: London and New York as global financial capitals, in BUDD, L. and WHIMSTER, S. (Eds.) Global Finance \& Urban Living: A Study of Metropolitan Change, London, Routledge.

\footnotetext{
${ }^{\mathrm{i}}$ These lacunae are striking considering that by 1776 Adam Smith, in Book IV of the Wealth of Nations, had already acknowledged the role played by investors in facilitating trade, and illustrated it with the example of
} 
Amsterdam as a concentration of financiers intermediating trade between Königsberg in Eastern Prussia and Lisbon (mainly corn in exchange for fruit and wine).

ii Other terms have been used by economic geographers and urban scholars to refer to high value industries servicing businesses, particularly in the professional, creative and financial sectors. Sassen (1991), Bryson and Daniels (1998) and Beaverstock et al. (1999) refer to 'advanced producer services' (APS) in examining their instrumental role in the globalisation of economic activities and city-centred configuration of global capitalism. 'Knowledge intensive business services' (KIBS) is a similar term that became more popular in the last decade with concurrent interest in developing knowledge based economies. KIBS emphasize knowledge intensive and expertise based business services and their contribution to urban and regional competitiveness (WOOD, 2006). In this paper, we have adopted the term ABS (following WÓJCIK, 2013b). While they have emerged out of slightly different contexts, APS, KIBS and ABS all highlight the centrality of such high order business services to the development of world cities, their vital role in driving economic globalization and the interconnected nature of finance and these professional business services.

iii GPNs can be defined as networks of interconnected economic and non-economic actors, coordinated by a global lead firm, and producing a good or service across multiple geographical locations for worldwide markets. They are thus constituted by relationships between firms of different sizes (and with other non-firm actors). iv Firms can also finance themselves from retained earnings and working capital, e.g. by delaying payments to their suppliers (BAUD and DURAND, 2012).

v See also DIXON (2010) on integrating financial geographies of the firm more fully into these literatures. vi This is not a new dynamic. The Dutch East India Company, for instance, plugged itself into a nascent international financial network through becoming a joint stock company and listing on the Amsterdam Stock Exchange.

vii This is reminiscent of the statement by an investment fund representative at an Annual Shareholder Meeting of Volkswagen that 'there is no point in VW just building perfect cars. It also needs to construct a perfect share price' (MAJOR, 2000).

viii Investment banking, at the core of the ABS has epitomized the strategy of maximizing net profits to equity ratio. Externally they have promoted shareholder value ideology throughout the corporate sector. Internally, they have used special investment and special purpose vehicles, as types of IVs, often booked in OJs to avoid taxation and regulation. They have focused on trading of financial instruments on their own account rather than servicebased activities, and used short-term funding to increase leverage (WÓJCIK, 2013b).

${ }^{\text {ix }}$ Although China Mobile is widely considered as China's first 'national champion', it is not a traditional 'national champion' understood in terms of success in exports and international markets. As of September 2013 China Mobile sold their services in China (including Hong Kong) and Pakistan only (WÓJCIK, 2013c). 